\title{
Follicullar Development and Embryo Recovery Following 3 versus 8 FSH Injections in Heifers
}

\author{
By B. Purwantara, M. Schmidt, H. Callesen and T. Greve \\ Department of Clinical Studies, Reproduction, The Royal Veternary and Agricultural University, Frede- \\ riksberg and Embryo Technology Center, Natıonal Institute of Anımal Scıence, Tjele, Denmark.
}

\begin{abstract}
Purwantara, B., M. Schmidt, H. Callesen and T. Greve: Follicullar development and embryo recovery following 3 versus 8 FSH injections in heifers. Acta vet. scand. 1994, 35, 89-92. - Ovarian follicular dynamıcs and embryo yield were studied during 2 different FSH regimens for superovulation of cattle. Twenty heifers were given intramuscular injections of FSH (total of $35 \mathrm{mg} \mathrm{NIH}$ ) either once daily for 3 days (Group $3 \times 1$ ) or twice daily for 4 days (Group $4 \times 2$ ). At $72 \mathrm{~h}$ after the first FSH injection, each anımal was injected with $0.75 \mathrm{mg}$ cloprostenol. Inseminations were performed at $12 \mathrm{~h}$ and $24 \mathrm{~h}$ after the onset of heat Transrectal ultrasonography was performed on the day of the first FSH injection, the day of cloprostenol injection, the day of insemination and finally on the day of embryo recovery (day 6 or 7 after heat). The numbers of small (2-4 $\mathrm{mm})$, medium $(5-9 \mathrm{~mm})$ and large $(>10 \mathrm{~mm})$ size follicles were recorded. The total number of corpora lutea, eggs and transferable embryos were recorded on the day of embryo recovery. No differences were found between the 2 groups in either of the parameters studied $(p>0.05)$. It can be concluded that treatment with this FSH preparation once daily for 3 days gives a folliculogenic and superovulatory response similar to a treatment regimen where it is given twice dally for 4 days.
\end{abstract}

cattle; follicles; growth; ultrasound; superovulation.

\section{Introduction}

Follicle stimulating hormone (FSH) is widely used for superovulation in cattle. Since FSH has a short half life (Laster 1972), multiple administrations, preferably 2 injections daily for 3-4 days, has been the general recommended schedule and this demands frequent handling of donor animals during the course of a superovulation regimen. In order to provide flexibility in this schedule and to minimize animal stress, particularly in beef donors, 1 injection a day or a total of 3 injections have been used (Donaldson 1990, 1991, Bo et al. 1991). No sig- nificant difference in embryo production was reported between 8 versus 3 injections when giving an equal dose (Donaldson 1990, 1991), whereas variable results were reported by $B o$ et al. (1991).

However, there is very limited information regarding folliculogenesis and other intraovarian changes during superovulation between these $2 \mathrm{FSH}$ regimens and the aim of this study was to compare folliculogenic changes and embryo recovery results between 2 FSH superovulation regimens, i.e. 8 or 3 injections of equal amounts of FSH. 


\section{Materials and methods}

\section{Animals}

Twenty normally cycling heifers of mixed breed were used in this experiment. The animals were housed in tie stalls and fed a balanced maintenance ratio. Prior to the superovulation, all animals received $0.50 \mathrm{mg}$ cloprostenol (Estrumat ${ }^{\circledR}$ Vet., Pitman-Moore, Frederiksberg, Denmark) injection im to induce estrus.

\section{Superovulation and embryo recovery}

FSH treatment was initiated on day 9-11 of the new estrus cycle. Each animal received intramuscular injections of FSH (Folltropin ${ }^{\circledR}$ Vet., Pitman-Moore) to give a total dose of 35 $\mathrm{mg}$ NIH/animal. The animals were randomly divided into 2 groups: In Group $3 \times 1(\mathrm{n}=10)$, the animals received decreasing doses of FSH once daily for 3 subsequent days (14 mg, 12.25 $\mathrm{mg}$ and $8.75 \mathrm{mg}$, respectively). Animals in Group $4 \times 2(n=10)$ received decreasing doses of FSH twice daily for 4 days $(2 \times 7.0 \mathrm{mg}$, $2 \times 5.25 \mathrm{mg}, 2 \times 3.50 \mathrm{mg}$ and $2 \times 1.75 \mathrm{mg}$, respectively). At $72 \mathrm{~h}$ after the initial FSH injection, all animals received a single injection im of $0.75 \mathrm{mg}$ cloprostenol (Estrumat ${ }^{\circledR}$ Vet., Pitman-Moore). Estrus detection was carried out twice daily and the animals were inseminated twice with a single dose of frozen semen from a bull with known normal fertility at approximately 60 and $72 \mathrm{~h}$ after the cloprostenol injection.

Non-surgical flushing of the uterus was performed on day 6 or 7 after estrus and the recovered ova were characterized as transferable embryos or not according to standard morphological evaluation of developmental stage and quality (Greve 1981, Lindner \& Wright 1983).

\section{Ultrasonography}

A real-time B-mode diagnostic ultrasound in- strument (Concept Ultrasound Scanner, Dynamic Imaging Ltd., United Kingdom) equipped with a $7.5 \mathrm{MHz}$ transrectal transducer was used to examine the ovaries on the day of initiation of the FSH treatment, the day of cloprostenol injection, the day of insemination and the day of embryo recovery. The follicles were categorized as small, medium or large size $(2-4,5-9$ or $\geq 10 \mathrm{~mm}$ in diameter, respectively). The number of corpora lutea was counted on the day of embryo recovery by means of ultrasonography as well as estimated by rectal palpation.

\section{Statistical analysis}

Mean number of small, medium, large and total follicles were analyzed and compared by Student t-test using Statistical Analysis System (SAS Institute Inc.). Similar analysis were performed to compare the number of ova recovered and transferable embryos.

\section{Results}

Six animals (60\%) in Group $3 \times 1$ and 9 animals $(90 \%)$ in Group $4 \times 2$ responded to the superovulation treatment with at least 2 corpora lutea on the day of embryo recovery. One animal from Group $4 \times 2$ exhibited a premature ovulation (Callesen et al. 1987) and was excluded for comparison of intraovarian follicular changes.

The mean number of follicles categorized as small, medium and large size on the 3 days of ultrasonography is shown in Table 1 . No differences were found in follicular distribution between the day of initiation of FSH, day of cloprostenol injection and the day of insemination $(\mathrm{P}>0.05)$. However, there was a tendency for Group $4 \times 2$ to generate a pool of large size follicles earlier than Group $3 \times 1$. Conversely, Group $3 \times 1$ tended to have a pool of medium size follicles earlier compared to Group 4×2. 
Table 1 Number of different size follicles (mean \pm SEM) in relation to different events durıng superovulation of cattle.

\begin{tabular}{llrrr}
\hline \multirow{2}{*}{$\begin{array}{l}\text { Treatment } \\
\text { group }\end{array}$} & $\begin{array}{l}\text { Follıcle } \\
\text { size group }\end{array}$ & \multicolumn{3}{c}{ Number of follıcles / anımal } \\
\cline { 3 - 5 } & & Day of FSH & Day of PG & Day of AI \\
\hline $3 \times 1$ & small & $23 \pm 2$ & $9 \pm 1$ & $8 \pm 1$ \\
$(\mathrm{n}=10)$ & medium & $1 \pm 1$ & $20 \pm 5$ & $15 \pm 3$ \\
& large & $1 \pm 1$ & $8 \pm 2$ & $17 \pm 5$ \\
$4 \times 2$ & small & $21 \pm 1$ & $10 \pm 1$ & $6 \pm 1$ \\
$(\mathrm{n}=9)$ & medium & $2 \pm 1$ & $14 \pm 4$ & $10 \pm 2$ \\
& large & $1 \pm 1$ & $11 \pm 2$ & $19 \pm 3$ \\
\hline
\end{tabular}

FSH: first injection of FSH.

PG: injection of cloprostenol.

AI: first insemination

The estimated number $( \pm$ SEM) of corpora lutea on the day of embryo collection tended to be higher in Group $4 \times 2$ than in Group $3 \times 1$, examined both by palpation and by ultrasonography $(4 \times 2: 10 \pm 3$ and $17 \pm 4 ; 3 \times 1: 8 \pm 4$ and $11 \pm 5$; respectively; $\mathrm{n}=10$ for both groups). These results also show that the number of corpora lutea is underestimated by rectal palpation as compared to the more accurate ultrasonography.

The mean number $( \pm$ SEM) of ova and transferable embryos recovered tended to be higher for Group $3 \times 1$ than for Group $4 \times 2$ (5.2 $\pm 3.6 / 3.2 \pm 1.8$ vs $4.9 \pm 1.2 / 1.7 \pm 0.9 ; \mathrm{n}=10$ for both groups). However, none of these numbers differed significantly between groups $(\mathrm{P}>0.05)$.

\section{Discussion}

The present study indicates that treatment with FSH (Folltropin ${ }^{\circledR}$ Vet.) 3 times with $24 \mathrm{~h}$ interval resulted in a folliculogenetic and superovulatory response as well as an eggand embryo yield that is similar to what is achieved after FSH treatment 8 times given twice daily for 4 days. This in agreement with early studies (Donaldson 1990, 1991) and pre- vious results from our laboratory (Schmidt et al. 1992). Furthermore, several recent studies (Hill et al. (1986), Bo et al. (1991), Yamamoto et al. (1992), Hockley et al. (1992), Misra et al. (1992)) revealed no significant difference in the superovulatory response between a single injection of FSH and the conventionally $4 \times 2$ regimen.

Taken together, these findings question the generally accepted treatment regimen for FSH, namely the necessity for frequent injections of FSH to achieve a satisfactory superovulatory response in cattle. Instead it seems likely that the level of FSH in the circulation only has to reach a minimum amount to trigger the follicular development.

The distribution of follicles in the defined size categories followed the general pattern described earlier (Purwantara et al. 1993), namely development of the pool of smaller follicles into the larger pool. Although not statistically significant, the pool of medium size follicles on the day of cloprostenol injection and insemination tended to be higher in Group $3 \times 1$ as compared to Group $4 \times 2$. The contrary pattern was observed for the pool of large follicles. A possible explanation for this is that the small follicles responded and grew faster in Group $3 \times 1$ as a consequence of the higher amount of FSH as opposed to the smaller amount administered in Group $4 \times 2$. It might be speculated that the peak level of FSH in the blood would be higher in Group $3 \times 1$, especially around $3 \mathrm{~h}$ after the first injection each morning. Further investigations are needed to elucidate whether different doses of FSH injection affect the development of follicle and changes of follicular pool in each category.

Palpation gave an underestimation of the number of corpora lutea as compared to the more accurate ultrasonography. This finding is in agreement with previous results (Greve 
1981, Monniaux et al. 1983) who argued that the accuracy of rectal palpation in counting the corpora lutea on the day of embryo collection is limited.

\section{Conclusion}

Treatment with an FSH preparation once daily for 3 days ( 3 times) results in a folliculogenic and superovulatory response (number of corpora lutea, number of ova and transferable embryos) similar to treatment twice daily for 4 days, i.e. 8 times.

\section{Acknowledgements}

This study was supported by Anımal Biotechnology Research Center and Danish Internatioal Development Agency (DANIDA).

\section{References}

Bo GA, Pierson RA, Mapletoft RJ: The effect of estradiol valerate on follicular dynamics and superovulatory response in cows with Synchro-mate-B implant. Theriogenology, 1992, 36, 169-183.

Callesen H, Greve T, Hyttel P. Premature ovulations in superovulated cattle. Theriogenology, 1987, $28,155-166$.

Donaldson LE: Embryo production by Super-ov and FSH-P. Theriogenology, 1990, 33, 214 (abstr).

Donaldson LE: The efficacy of 3 superovulation regimens in cattle. Theriogenology, 1991, 35, 195 (abstr).

Greve T: Bovine egg transplantation in Denmark Dr vet.Sc1. Thesis, Copenhagen, Denmark 1981 $221 \mathrm{pp}$.

Hill KG, Bondiols KR, Looney CR: Norgestomet incorporation into a superovulation regime. Therlogenology, 1986, 25, 160 (abstr.).

Hockley DK, Bo GA, Palasz AT, Del Campo MR, Mapletoft RJ: Superovulation with a single subcutaneous injection of Folltropin in the cow' Effect of dose and site of injection. Theriogenology, 1992, 37, 224 (abstr.).

Laster DB: Disappearance and uptake of (125 I) FSH in the rat, rabbit, ewe and cow. J. Reprod. Fert., 1972, 30, 407-415.

Lindner GM, Wright RW Jr: Bovine embryo morphology and evaluation. Theriogenology, 1983 20, 407-416.
Misra AK, Chaubal SA, Krisna Kishore G, Rajeshwaran S, Joshı BV, Jalswal RS: Superovulatory response to single subcutaneous injection of Folltropin in holstein and sahiwal cows. Theriogenology, 1992, 37, 260 (abstr.).

Monniaux D, Chupin D, Saumande J: Superovulatory response of cattle. Theriogenology, 1983, 19, 55-64.

Purwantara B, Schmidt M, Greve T, Callesen H: Follicular dynamics proor to and during superovulation in cattle Theriogenology, 1993, 40, 913-21.

Schmidt M, Purwantara B, Callesen H, Klindt K, Greve T: The effect of 3 versus 8 injections with 1dentical doses of Folltropin Vet ${ }^{\circledR}$ on the embryo recovery in dairy cows. Proc. 8th Scientific Meeting of Europ. Emb. Transfer Assoc., Lyon, 1992, 210 (abstr.).

Yamamoto M, Suzukı T, Ooe M, Tagakı M, Kawaguchı $M \cdot$ Efficacy of single vs multiple injection superovulation regimens of FSH using polyvinylpyrrol1done. Theriogenology, 1992, 37, 325 (abstr.).

\section{Sammendrag \\ Follıkeludvikling of embryoproduktion efter behand- ling af kvier med 3 versus 8 FSH injektioner.}

Den ovarielle follıkeldynamık samt embryoproduktionen blev unders $\varnothing \mathrm{gt}$ for to forskellige FSH protokoller til superovulation af kvæg. Tyve kvier fik intramuskulære injektioner med FSH (1 alt $35 \mathrm{mg}$ ) enten én gang daglig 1 tre dage (Gruppe $3 \times 1$ ) eller to gange daglig 1 fure dage (Gruppe $4 \times 2$ ). Ved 72 tımer efter den første FSH injektion fik hvert dyr $0.75 \mathrm{mg}$ cloprostenol og blev insemineret 12 og 24 timer efter brunstens begyndelse. Transrektal ultralydsunders $\varnothing$ gelse blev gennemf $\varnothing r t$ på dagene for den første FSH injektion, for cloprostenol injektion, for insemination og for opsamlıng af embryoner (dag 6 eller 7 efter brunst), 1det små (2-4 mm), medium ( $5-9 \mathrm{~mm})$ og store $(>10 \mathrm{~mm})$ follikler blev talt Det totale antal corpora lutea, æg og overførbare embryoner blev noteret på dagen for embryo opsamling. Ingen forskel blev fundet mellem de to grupper 1 nogen af de undersøgte parametre $(\mathrm{P}>0.05)$. Det konkluderes, at behandling med dette FSH præparat én gang daglig 1 tre dage giver et tilsvarende follikulogenetskk og superovulationsmæssigt svar, som opnås, hvis FSH gives to gange daglig i fire dage.

(Recelved August 31, 1993; accepted December 16, 1993).

Reprints may be requested from: M. Schmıdt, Department of Clinıcal Studies, Reproduction, The Royal Veterinary and Agricultural Unıversity, Bulowsvej13, DK-1870 Frederiksberg C, Denmark. 